\title{
HUBUNGAN ANTARAINDEKS MASSA TUBUHDENGAN KADAR TRIGLISERIDA PADA PASIEN FKTP DIABETES MELITUS TIPE II DI DOKTER PRAKTIK MANDIRI K-HAKIKIYAHLAMPUNG TENGAH AGUSTUS 2019
}

\author{
Zulfian $^{1}$, Firhat Esfandiari ${ }^{2}$, Selvia Anggraeni ${ }^{3}$, Ayu Selviani $^{4}$ \\ ${ }^{1}$ Departemen Patologi Klinik RS Pertamina Bintang Amin \\ ${ }^{2}$ Departemen PenyakitDalam Fakultas Kedokteran Universitas Malahayati \\ ${ }^{3}$ Staf Pengajar Fakultas Kedokteran Universitas Malahayati \\ ${ }^{4}$ Program Studi Kedokteran Fakultas Kedokteran UniversitasMalahayati
}

[email korespondensi: AyuSelviani27@gmail.com]

\begin{abstract}
Relation Of Body Mass Index (BMI) With Trigliserid Levels In Patient Diabetes Mellitus Type II FKTP In Independent Practice Doctor Of K.Hakikiyah Central Lampung Augustin 2019. Excess weight is a situation that is almost close to obesity, where a person can be declared overweight if the person has a BMI $\geq 23$. Excessive fat deposits in the body of patients with excess weight or obesity can lead to insulin resistance which affects the patient's blood sugar levels diabetes mellitus. Without weight loss and lifestyle modification, people with metabolic syndrome have a significant risk of becoming type 2 diabetes mellitus so prevention.To find out the relationship between Body Mass Index (BMI) and Triglyceride levels in patient Diabetes Mellitus type II FKTPin mandiri Practices doctor of K- Hakikiyah Central Lampung in August 2019. This type of research uses analytic-observational methods with cross-sectional approach, namely the way and data collection is done at once without providing certain treatment to the research object, the population of this study is all patients with type II Diabetes Mellitus in the Independent Practitioners of the Law Practitioner K. Hakikiyah Central Lampung August 2019. The sampling technique in this study is the total sampling quota, the entire population being a sample of 59 people. Data analysis performed was univariate and bivariate with chi-square test. The most body mass index of IMT was in overweight category with total of 30 people $(53.6 \%)$. The highest frequency distribution of triglyceride levels is in the normal category of 22 people (39.3\%). It was foundthat there was a relationship between Body Mass Index (BMI) between triglyceride levels in type II diabetes mellitus FKTP patients at the K-Hakikiyah Central Lampung independent practice physician in August 2019 with a $\mathrm{p}$-value $=$ 0.019.It is know that There is a relationship between Body Mass Index (BMI) between Triglyceride levels in type II diabetes mellitus FKTP patients at the KHakikiyah Central Lampung independent practice physician in August 2019.
\end{abstract}

Keywords: body mass index (BMI), Triglyceride, Diabetes Melitus

\begin{abstract}
Abstrak :Hubungan Antara Indeks Massa Tubuh (IMT) Dengan Kadar Trigliserida Pada Pasien FKTP Diabetes Mellitus Tipe II Di Praktik Dokter Mandiri K.Hakikiyah Lampung Tengah Agustus 2019. Berat badan berlebih adalah keadaan yang hampir mendekati obesitas, di mana seseorang dapat dinyatakan berat badan berlebih apabila orang tersebut memiliki IMT $\geq 23$. Timbunan lemak yang berlebihan di dalam tubuh penderita berat badan berlebih atau obesitas dapat mengakibatkan resistensi insulin yang berpengaruh terhadap kadar gula darah penderita diabetes melitus. Tanpa adanya penurunan berat badan dan modifikasi gaya hidup, orang dengan sindrom metabolik memiliki resiko bermakna untuk menjadi diabetes melitus tipe 2 sehingga perlu dilakukan pencegahan serta pengendalian untuk tidak memperburuk kondisi pasien tersebut.untuk mengetahui Apakah terdapat hubungan antaraIndeks Massa Tubuh (IMT) dengan kadar Trigliserida pada pasien FKTP Diabetes Mellitus tipe II di Dokter Praktik Mandiri K.Hakikiyah Lampung Tengah Agustus Tahun 2019.Jenis penelitian ini menggunakan metode Analitik-observastional dengan pendekatan cross-sectional, yaitu cara dan pengambilan data dilakukan sekaligus tanpa
\end{abstract}


pemberian perlakuan tertentu terhadap objek penelitian,Populasi dari penelitian ini adalah seluruh pasien Diabetes Melitus tipe II di Dokter Praktik Mandiri K. Hakikiyah Lampung Tengah Agustus Tahun 2019.Tehnik Pengambilan sampel pada penelitian ini adalah Kuota total sampling, keseluruhan populasi menjadi sampel yang berjumlah 59 orang. Analisa data yang dilakukan adalah univariat dan bivariat dengan uji chi-square. Distribusi frekuensi Indeks Massa Tubuh IMT terbanyak yaitu kategoriberlebih sebanyak 30 orang $(53,6 \%)$. Distribusi frekuensi kadar Trigliserida terbanyak yaitu kategori normal sebanyak 22 orang (39,3\%). Di ketahui ada hubungan antara Indeks Massa Tubuh (IMT) antara kadar Trigliserida pada pasien FKTP diabetes melitus tipe II di dokter praktik mandiri K-Hakikiyah Lampung Tengah Agustus tahun 2019 dengan nilai p-value = 0,019. Ada hubungan antara Indeks Massa Tubuh (IMT) antara kadar Trigliserida pada pasien FKTP diabetes melitus tipe II di dokter praktik mandiri K-Hakikiyah Lampung Tengah Agustus 2019.

Kata Kunci : Indeks Masa Tubuh, Kadar Trigliserida, Diabetes Melitus tipe II

\section{PENDAHULUAN}

Diabetes

mellitus

(DM)

merupakan suatu sindrom gangguan metabolisme karbohidrat, lemak dan protein yang disebabkan oleh kurangnya sekresi insulin atau penurunan sensitifitas jaringan terhadap insulin yang bersifat kronis yang ditandai dengan peningkatan konsentrasi glukosa darah (Bilous \& Donelly, 2014). International Diabetes Federation (IDF) menyebutkan bahwa prevalensi diabetes mellitus di dunia adalah $1,9 \%$ dan telah menjadikan DM sebagai penyebab kematian urutan ke tujuh di dunia sedangkan tahun 2013 angka kejadian diabetes di dunia adalah sebanyak 382 juta jiwa dimana proporsi kejadian DM tipe II adalah 95\% dari populasi dunia. Prevalensi kasus Diabetes mellitus tipe II sebanyak 85-90\% (Bustan, 2015).

Indonesia menempati peringkat ke-7 sebagai negara dengan jumlah penderita Diabetes Mellitus terbanyak di dunia, yaitu dengan 10 juta penderita dan diperkirakan akan meningkat menjadi 16,2 juta penderita pada tahun 2040 (International Diabetes Federation, 2015). Indonesia menempati peringkat kedua kasus Diabetes Mellitus terbanyak di daerah pasifik setelah China yang berada di peringkat pertama (International Diabetes Federation, 2015). Insiden Diabetes Melitus meningkat dalam berbagai penelitian. Penelitian di Indonesia termasuk jakarta dan kota lainnya menunjukan adanya peningkatan. Peningkatan insiden DM akan memengaruhi peningkatan kejadian komplikasi kronik. Komplikasi kronik dapat terjadi khususnya pada penderita Diabetes Melitus tipe II (Waspadji, 2009).

Kemenkes RI (2015). Diabetes Melitus tipe II yang terbanyak di indonesia. Dari 8,4 juta pada tahun 2016 diperkirakan akan menjadi 21,3 juta pada tahun 2030. Jumlah penderita di Indonesia yang menderita penyakit Diabetes Mellitus Tipe II sebesar $5,7 \%$ dari keseluruhan jumlah penduduk dan $1,1 \%$ diantaranya meninggal dunia karena Diabetes Mellitus Tipe II. Data Profil Kesehatan Provinsi Lampung Tahun 2016 prevalensi Diabetes Mellitus adalah $0,6 \%$.

Data dari Riskesdas menyebutkan bahwa prevalensi penderita Diabetes Mellitus cenderung meningkat pada perempuan dibandingkan dengan lakilaki, dimana terjadi peningkatan prevalensi penyakit Diabetes Mellitus sesuai dengan pertambahan umur namun pada umur $\geq 65$ tahun prevalensi Diabetes Mellitus cenderung menurun. Prevalensi Diabetes Mellitus cenderung lebih tinggi bagi penderita yang tinggal di perkotaan dibandingkan dengan di pedesaan.

Ditinjau dari segi pendidikan menurut Riskesdas bahwa prevalensi Diabetes Mellitus cenderung lebih tinggi pada masyarakat dengan tingkat pendidikan tinggi (Dinkes, 2016). Angka kejadian diabetes melitus di Provinsi Lampung untuk rawat jalan pada tahun 2009 perbulan rata-rata 
mencapai 365 orang dan mengalami peningkatan pada tahun 2010 menjadi 1103 orang (Dinkes, 2011). Angka kejadian diabetes melitus di Kabupaten Lampung Tengah berdasarkan data di Dinas Kesehatan Lampung Tengah mengalami peningkatan sebesar $9 \%$ yaitu sebanyak 581 kasus (Dinkes, 2012).

Status gizi memiliki pengaruh terhadap kejadian DM tipe II (DMT2). IMT tinggi mempunyai resiko 2 kali lebih besar untuk terkena DMT2 dibandingkan dengan IMT rendah. Hasil penelitian menunjukan bahwa obesitas umum beresiko 2,24 kali sedangkan obesitas abdominal beresiko 2,44 kali untuk terjadinya Diabetes Mellitus. Peningkatan trigliserida (hipertrigliseridemia) merupakan faktor resiko terjadinya penyakit jantung koroner dan stroke. Kadar trigliserida tinggi juga sangat cenderung menyebabkan gangguan tekanan darah dan resiko Diabetes Mellitus(Agnes, 2014).

Kenaikan

berhubungan

kegemukan.

berdampak

bergerak, produktivitas kerja, dan penurunan kesehatan (Wardina, 2009) Responden dengan Indeks Massa Tubuh berlebihan memiliki resiko tiga kali lebih tinggi mengalami hipertrigliseridemia (Sara, 2009).

\section{METODE}

Jenis penelitian ini menggunakan metode Analitik-observastional dengan pendekatan cross-sectional,Populasi dari penelitian ini adalah seluruh pasien Diabetes Melitus tipe II di Dokter Praktik Mandiri K.Hakikiyah Lampung Tengah Agustus Tahun 2019. Penarikan menggunakantotal sampling dengan jumlah sampel 56 orang. Analisa data yang dilakukan adalah univariat dan bivariat dengan uji chi-square.

\section{HASIL}

Analisis univariat dalampenelitian ini untuk mengetahui distribusi frekuensi usia, distribusi frekuensi jenis kelamin, distribusi frekuensi indeks massa tubuh, dan distribusi frekuensi trigliserida pada pasien FKTP DMT2 di dokter praktik mandiri K. Hakikiyah Lampung Tengah Agustus 2019. Sedangkan analisis bivariat dalam penelitian ini untuk mengetahui hubungan indeksmassa tubuh (IMT) dan kadar trigliserida padapasien FKTP DMT2 di dokter praktik mandiri K. Hakikiyah Lampung Tengah Agustus 2019. Responden dalam penelitian ini berjumlah 56 orang, semua responden memenuhi kriteria inklusi, sehingga seluruhnya dijadikan sampel. Hasil penelitian dari 56 responden didapat pada tabel 1 di bawah.

Berdasarkan tabel 1 dapat dilihat bahwa dari 56 subjek penelitian berdasarkan umur, di dapatkan umur dengan katagori tidak beresiko ( $<45$ th) sebanyak 7 responden (12,5\%), lebih sedikit di banding umur dengan katagori beresiko ( $\geq 45$ th) sebanyak 49 responden $(87,5 \%)$, dan untuk subjek penelitian berdasarkan jenis kelamin sebagian besar berjenis kelamin perempuan berjumlah 32 responden $(57,1 \%)$, sedangkan sisanya berjenis kelamin laki-laki berjumlah 24 responden (42,9\%).

Berdasarkan tabel 2 diketahui bahwa dari 56 responden yang diteliti,terlihat bahwa yang terbanyak dengan IMT kategoriberlebih sebanyak 30 orang $(53,6 \%)$ selebihnya didapatkanIMT kategori normal yaitu 26 orang $(46,4 \%)$. Berdasarkan tabel 3 diketahui bahwa dari 56 responden yang diteliti, terlihat bahwa yang terbanyak dengan kadar trigliserida kategori berlebihsebanyak 43 orang $(76,8 \%)$, selebihnya didapatkan kadar trigliserida kategori normal yaitu 13 orang $(23,2 \%)$.

Berdasarkan tabel 4 menunjukan bahwa IMT kategori normal terdapat 15 orang $(68,2 \%)$ dengan kondisi kadar trigliserida kategori normal dan 11 orang $(32,4 \%)$ dengan kadar trigliserida kategori berlebih. Sedangkan IMT kategori berlebih terdapat 7 orang $(31,8 \%)$ dengan kadar trigliserida kategori normal dan 23 orang $(67,6 \%)$ dengan kadar trigliserida kategori berlebihan . Hasil uji statistik diperoleh nilai P-value $0,019$ ( $P$-value $<0,05)$. Berarti dapat disimpulkan bahwa terdapat hubungan indeks massa tubuh (IMT) dan kadar 
trigliserida pada pasien FKTP DMT2 di

dokter praktik mandiri K. Hakikiyah

Tabel 1. Tabel Distribusi Frekuensi karakteristik responden berdasarkan Umur dan Jenis Kelamin dengan Trigliserida pada pasien FKTP DMT2 di dokter praktik mandiri K. Hakikiyah Lampung Tengah Agustus 2019

\begin{tabular}{lcc}
\hline \multicolumn{1}{c}{ Karakteristik } & Jumlah & Persentase \\
\hline Usia (Tahun) & 7 & \\
Tidak Beresiko (<45 th) & 49 & $12,5 \%$ \\
Beresiko ( $\geq 45$ th) & & $87,5 \%$ \\
& & \\
Jenis Kelamin & 24 & $42,9 \%$ \\
Laki - Laki & 32 & $57,1 \%$ \\
Perempuan & 56 & $100 \%$ \\
Total & & \\
\hline
\end{tabular}

Tabel 2. Distribusi frekuensi Indeks Massa Tubuh (IMT) pada pasien FKTP DMT2 di dokter praktik mandiri K. Hakikiyah Lampung Tengah Agustus 2019

\begin{tabular}{ccc}
\hline $\begin{array}{c}\text { Indeks Massa Tubuh } \\
\text { (IMT) }\end{array}$ & Jumlah & Persentase \\
\hline Normal & 26 & $46,4 \%$ \\
Berlebih & 30 & $53,6 \%$ \\
Total & 38 & 100 \\
\hline
\end{tabular}

Tabel 3. Distribusi frekuensi Kadar Trigliserida pada pasien FKTP DMT2 di dokter praktik mandiri K. Hakikiyah Lampung Tengah Agustus 2019

\begin{tabular}{ccc}
\hline Kadar Trigliserida & Jumlah & Persentase \\
\hline Normal & 13 & $23,3 \%$ \\
Meningkat & 43 & $76,8 \%$ \\
Total & 56 & 100 \\
\hline
\end{tabular}

Tabel 4. Hubungan antara Indeks Massa Tubuh (IMT) dan Kadar Trigliserida pada pasien FKTP DMT2 di dokter praktik mandiri K. Hakikiyah Lampung Tengah Agustus 2019

\begin{tabular}{|c|c|c|c|c|c|c|c|c|}
\hline \multirow{3}{*}{$\begin{array}{c}\text { Indeks } \\
\text { Massa } \\
\text { Tubuh } \\
\text { (IMT) }\end{array}$} & \multicolumn{4}{|c|}{ Kadar Hb-A1c } & \multirow{2}{*}{\multicolumn{2}{|c|}{ Jumlah }} & \multirow{3}{*}{$\begin{array}{c}P- \\
\text { value }\end{array}$} & \multirow{3}{*}{$\mathrm{Cl}(95 \%)$} \\
\hline & \multicolumn{2}{|c|}{ Normal } & \multicolumn{2}{|c|}{ Meningkat } & & & & \\
\hline & $\mathbf{N}$ & $\%$ & $\mathbf{N}$ & $\%$ & $\mathbf{N}$ & $\%$ & & \\
\hline Normal & 15 & 68,2 & 11 & 32,4 & 26 & 100 & & 2,473 \\
\hline Berlebih & 7 & 31,8 & 23 & 53,6 & 30 & 100 & 0,005 & $(1,195-$ \\
\hline Total & 22 & & 34 & & 56 & 100 & & $5,117)$ \\
\hline
\end{tabular}




\section{PEMBAHASAN}

Berdasarkan tabel 2 diketahui bahwa dari 56 responden yang diteliti,terlihat bahwa yang terbanyak dengan IMT kategori berlebih sebanyak 30 orang $(53,6 \%)$ selebihnya didapatkan IMT kategori normal yaitu 26 orang $(46,4 \%)$.

IMT merupakan alat atau cara yang sederhana untuk memantau status gizi orang dewasa khususnya yang berkaitan dengan kekurangan dan kelebihan berat badan. Berat badan yang kurang dapat meningkatkan risiko terhadap penyakit infeksi, sedangkan berat badan berlebih akan meningkatkan resiko terkena penyakit degeneratif, sehingga mempertahankan berat badan normal memungkinkan seseorang dapat mencapai usia harapan hidup yang lebih panjang (Supariasa dkk, 2012).

Hasil IMT yang masuk kategori berat badan berlebih perlu diwaspadai.Berat badan berlebih merupakan faktor resiko yang berperan penting terhadap penyakit diabetes melitus.Orang dengan berat badan berlebih memiliki masukan kalori yang berlebih. Sel beta kelenjar pankreas akan mengalami kelelahan dan tidak mampu untuk memproduksi insulin yang cukup untuk mengimbangi kelebihan masukan kalori. Akibatnya kadar glukosa darah akan tinggi yang akhirnya akan menjadi DM (Sugiritama, 2015).

Menurut peneliti timbunan Iemak yang berlebihan di dalam tubuh penderita obesitas dapat mengakibatkan resistensi insulin yang berpengaruh terhadap kadar gula darah yang menyebabkan terjadinya diabetes melitus. Kelebihan berat badan baik tingkat ringan maupun sedang, karena kelebihan berat badan meningkatkan resiko penyakit degeneratif, dimana diabetes melitus merupakan salah satu penyakit degeneratif. Berdasarkan tabel 3 diketahui bahwa dari 56 responden yang diteliti, terlihat terlihat bahwa yang terbanyak dengan kadar trigliserida kategori berlebih sebanyak 34 orang $(60,7 \%)$, selebihnya didapatkan kadar trigliserida kategori normal yaitu 22 orang (39,3\%).
Diabetes Melitus (DM) merupakan suatu kelompok penyakit metabolik dengan karakteristik hiperglikemia yang terjadi karena kelainan sekresi insulin, kerja insulin atau keduaduanya. Secara global terdapat 382 juta orang yang hidup didunia dengan diabetes pada tahun 2013, dan pada tahun 2035 akan meningkat menjadi 592 juta orang dengan diabetes mellitus. Dua kelainan fisiologis utama pada prediabetes adalah resistensi insulin dan disfungsi sel beta pankreas, dan perubahan ini terwujud sebelum terjadinya kelainan kadar glukosa (WHO,2017).

Trigeliserida adalah salah satu bentuk lemak yang diserap oleh usus setelah mengalami hidrolisis, kemudian masuk ke dalam plasma. Trigliserida merupakan lemak darah yang akan meningkat ketika mengkonsumsi alkohol, mengalami peningkatan berat badan dan mengkonsumsi makanan dengan kadar gula tinggi (Sutanto, 2010).

Pernah ada anggapan bahwa level trigliserida yang tinggi tidak menjadi masalah sepanjang tidak ada faktor risiko lain. Penyebab kondisi kesehatan bertambah buruk adalah factor ikutan yang menemani level trigliserida, misalnya level trigliserida yang tinggi dijumpai pada orang yang menderita DM, hypertensi dan obesitas. Hal ini yang diyakini oleh para ilmuwan memperbesar resiko penyakit jantung (Khomsan, 2006).

Berdasarkan tabel 4 menunjukan bahwa IMT kategori normal terdapat 15 orang $(68,2 \%)$ dengan kondisi kadar trigliserida kategori normal dan 11 orang $(32,4 \%)$ dengan trigliserida kategori berlebih. Sedangkan IMT kategori berlebih terdapat 7 orang $(31,8 \%)$ dengan kadar trigliserida kategori normal dan 23 orang $(62,6 \%)$ dengan kadar trigliserida kategori berlebih. Hasil uji statistik diperoleh nilai P-value0,019 (P-value $<0,05)$ yang berarti $\mathrm{Ha}$ diterima dan $\mathrm{Ho}$ ditolak. Berarti dapat disimpulkan bahwa terdapat hubungan indeks massa tubuh (IMT) dengan kadar trigliserida pada pasien FKTP DMT2 di Dokter Praktik Mandiri K. Hakikiyah Lampung Tengah Agustus 2019. 
Hasil penelitian ini sejalan dengan Sanlier dimana hasil penelitian menunjukkan bahwa responden yang mengalami obesitas, mayoritas obesitas derajat I dan kategori kejadian diabetes mellitus nilai uji chisquare yaitu 0,01 yang berarti a < 0,05 . Hal ini menunjukkan bahwa ada hubungan yang signifikan antara obesitas dengan kejadian diabetes mellitus. Hasil penelitian ini menyebutkan bahwa semakin besar IMT maka semakin besar risiko menderita diabetes melitus.

Overweight dan obesitas yang keduanya didefinisikan sebagai kelebihan berat badan, secara umum merupakan keadaan kegemukan dengan perbedaan tingkatan yaitu kelebihan berat badan tingkat ringan (overweight) dan tingkat berat (obesitas) yang dibedakan sesuai dengan kriteria kegemukan berdasarkan pengukuran indeks massa tubuh (IMT) atau disebut juga body mass index(BMI). Overweight adalah keadaan yang hampir mendekati obesitas, seseorang dapat dinyatakan overweight apabila orang tersebut memiliki IMT $\geq 23$. Selain itu, kondisi overweight juga lazim disebut dengan kondisi pre-obese (WHO, 2010).

Diabetes melitus terjadi pada orang yang memiliki status gizi gemuk atau tidak gemuk. Namun sebagian besar DMT2 terjadi pada orang obesitas/ overweight. Hubungan antara obesitas dengan DMT2 telah diketahui sejak beberapa dekade sebelumnya, dimana obesitas viseral sering ditemukan pada sebagian besar pasien. Resistensi insulin ditemukan bahkan pada obesitas sederhana yang tidak diikuti oleh hiperglikemia, menunjukan suatu abnormalitas yang mendasar pada pengisyaratan insulin dalam keadaan kelebihan lemak. Istilah sindrom metabolik telah dipakai untuk sekelompok temuan yang didominasi oleh obesitas viseral, diikuti oleh resistensi insulin, intoleransi glukosa, dan faktor resiko seperti tekanan darah tinggi dan profil lemak yang abnormal (Perkeni, 2015).

Hasil penelitian ini berbeda dengan penelitian yang dilakukan Chainurridha (2014). Berdasarkan hasil penelitian ditemukan tidak ada hubungan antara IMT dengan kolesterol total, LDL serta trigliserida. Hal ini juga dapat disebabkan karena sebagian besar pasien telah menjalani pengobatan sehingga telah terjadi perubahan terhadap kadar profil lipid. Hasil ini didukung oleh hasil penelitianChainurridha (2014), di Aceh juga menyatakan bahwa tidak ada hubungan yang signifikan antara IMT dengan dengan hiperkolesterolemia, peningkatan LDL, dan hipertrigliseridemia namun terdapat korelasi bermakna dengan HDL.

Faktor resiko meningkatnya jumlah penderita DM dapat dikelompokkan oleh faktor resiko yang tidak dimodifikasi diantaranya adalah ras dan etnik, umur, jenis kelamin, riwayat keluarga dengan DM, riwayat melahirkan bayi dengan BB > 4000gr dan riwayat lahir dengan berat badan lahir rendah < 2500gr. Sedangkan faktor resiko yang dapat dimodifikasi berhubungan dengan perilaku hidup yang kurang sehat, yaitu berat badan lebih, obesitas abdominal/ sentral, kurangnya aktivitas fisik, hipertensi, dislipidemia, diet tidak sehat/ tidak seimbang, riwayat TGT/ GDPT dan merokok (Kemenkes RI, 2013).

Timbunan lemak yang berlebihan di dalam tubuh penderita obesitas dapat mengakibatkan resistensi insulin yang berpengaruh terhadap kadar gula darah penderita diabetes melitus. IMT lebih dari sama dengan $25 \mathrm{~kg} / \mathrm{m} 2$ pada orang dewasa dengan obesitas menyebabkan reseptor insulin pada target sel di seluruh tubuh kurang sensitif dan jumlahnya berkurang sehingga insulin dalam darah tidak dapat dimanfaatkan yang berdampak pada penurunan penyerapan gula darah pada jaringan sehingga kadar gula darah meningkat (Ilyas dalam Soegondo, 2007).

Tanpa adanya penurunan berat badan dan modifikasi gaya hidup, orang dengan sindrom metabolik memiliki resiko bermakna untuk menjadi DMT2 bermakna, menekankan pentingnya obesitas pada penyakit ini. Resiko diabetes meningkat seiring dengan peningkatan indeks massa tubuh (suatu pengukuran kandungan lemak tubuh) 
mengasumsikan adanya hubungan yang terkait dosis antara lemak tubuh dan resistensi insulin (Kumar, 2015).

\section{KESIMPULAN}

Berdasarkan hasil penelitian mengenai Hubungan Indeks Massa Tubuh (IMT) dengan Kadar Kolesterol Total Pada Pasien FKTP Diabetes Melitus Tipe II Di Praktik Mandiri Dokter K. Hakikiyah Lampung Tengah Agustus 2019, di peroleh kesimpulan sebagai berikut:

1. Diketahui distribusi frekuensi umur pada Praktik Mandiri Dokter K. Hakikiyah Lampung Tengah di peroleh dari 56 responden berdasarkan umur terbanyak yakni kategori beresiko ( $\geq 45$ th) sebanyak 49 responden $(87,5 \%)$.

2. Diketahui distribusi frekuensi jenis kelamin pada Praktik Mandiri Dokter K. Hakikiyah Lampung Tengah di peroleh dari 56 responden berdasarkan jenis kelamin terbanyak yakni pada jenis kelamin perempuan berjumlah 32 responden $(57,1 \%)$.

3. Diketahui distribusi frekuensi kadar trigliserida pada Praktik Mandiri Dokter K. Hakikiyah Lampung Tengah di peroleh dari 56 responden berdasarkan kadar trigliserida terbanyak yaitu kategori berlebih sebanyak 34 orang $(60,7 \%)$.

4. Diketahui distribusi frekuensi IMT pada Praktik Mandiri Dokter K. Hakikiyah Lampung Tengah di peroleh dari 56 responden berdasarkan IMT terbanyak yaitu kategori berlebih sebanyak 30 orang $(53,6 \%)$.

5. Diketahui ada hubungan indeks massa tubuh (IMT) dengan kadar trigliserida pada Praktik Mandiri Dokter K. Hakikiyah Lampung Tengah dengan nilai $p$-value = 0,019 .

\section{SARAN}

Saran yang dapat peneliti

sampaikan pada penelitian ini adalah :

1. Bagi Institusi Kesehatan

Disarankan bagi instansi pencegahan ditujukan untuk masyarakat yang berisiko tinggi yaitu melakukan skrining pemeriksaan laboratorium kadar gula darah terutama dengan berat badan yang obesitas karena menyebabkan reseptor insulin pada target sel di seluruh tubuh kurang sensitif. Sehingga dibutuhkan pola hidup yang sehat seperti pola makan, aktivitas fisik yang rutin, sehingga kadar glukosa darah terpantau baik.

2. Bagi Masyarakat

Disarankan bagi masyarakat agar mengikuti program skrining gula darah yang diadakan oleh pemerintah/instansi terkait, menjaga pola hidup sehat.

3. Bagi peneliti selanjutnya

Diharapkan dapat melakukan penelitian dengan jumlah subjek yang lebih besar, karna dalam Desain cross-sectional semakin banyak subjek penelitian maka semakin memperkuat kesimpulan.

\section{DAFTAR PUSTAKA}

Agnes. (2014). Biokimia Kesehatan. Yogyakarta: Nuha Medika.

Bilous, R \& Donelly, R.(2014). Buku Pegangan Diabetes. Edisi 4. Jakarta: Bumi Medika.

Bustan. (2015). Manajemen pengendalian penyakit tidak menular. Jakarta : Rineka Cipta.

Chainurridha. (2014). Hubungan Indeks Massa Tubuh dan Lingkar Perut pada Pasien Dislipidemia di Poli Endokrin dan Metabolik RSUD Dr. Zainoel Abidin Banda Aceh Tahun 2014.

Dinkes. (2011). Profil Data Kesehatan Kota Bandar Lampung tahun 2011. Dinas Kesehatan Provinsi Lampung. Lampung.

Dinkes. (2012). Profil Data Kesehatan Kabupaten Lampung Tengah tahun 2012.

Dinkes. (2016).Profil Data Kesehatan Kota Bandar Lampung tahun 2016. Dinas Kesehatan Provinsi Lampung. Lampung.

lyas, E.I. (2007). Manfaat Latihan Jasmani bagi Penyandang Diabetes, dalam Soegondo, S., et al. Penatalaksanaan Diabetes Melitus Terpadu, Jakarta: FKUI. 
International Diabetes Federation. (2015). IDF Diabetes Atlas Seventh Edition 2015.

Kemenkes RI. (2013). Waspada diabetes. Website : depkes.go.id/resources/download $L \quad$ pusdatin/infodatin/infodatindiabetes.pdfDiakses tanggal 25 Desember 2018.

Kemenkes RI. (2015). Profil Kesehatan Indonesia $2015 . \quad J a k a r t a:$ Kementrian Kesehatan RI, 2015.

Khomsan,A. (2006). Solusi Makanan Sehat. Jakarta: PT. RajaGrafindo Perkasa.

Kumar dkk. (2015). Buku Ajar Patologi Robbins. Edisi 9. Singapore: Penerbit Hooi Ping Che hal : 728731.

PERKENI. (2015). Konsensus Pengelolaan dan Pencegahan Diabetes Mellitus tipe 2di Indonesia. Perkumpulan Endikrinologi Indonesia: PB PERKENI.

Sara, J.S. (2009). Hubungan Indeks Massa Tubuh dengan Keadaan Biokimia Darah pada Karyawan PT. Asuransi Jiwa Bumi Asih Jaya, Jakarta. Analisis Data Sekunder 2008.Diakses dari lontar.ui.ac.id/file?file=digital/12.

Sugiritama. (2015). Gambaran IMT Kategori Berat Badan Lebih Dan Obesitas Pada Masyarakat Banjar Demulih, Kecamatan Susut, Kabupaten Bangli,Bali : FK Udayana.

Supariasa, dkk. (2012), Penilaian Status Gizi. Jakarta:EGC.

Sutanto. (2010). Cekal(Cegah dan Tangkal) Penyakit Modern : Hipertensi, Stroke, Jantung, Kolesterol dan Diabetes (gejalagejala, Pencegahan dan pengendalian). Yogyakarta: Penerbit ANDI

Wardina, S. (2009). Faktor Gaya Hidup Dalam Hubungannya Dengan Risiko Kegemukan Orang Dewasa Di Provinsi Sulawesi Utara, DKI Jakarta, Dan Gorontalo. Skripsi.

Waspadji S. (2009). Komplikasi Kronik Diabestes, Mekanisme Terjadinya, Diagnosis dan Strategi Pengelolaan. Buku Ajar Penyakit
Dalam: Jilid III, Edisi 4. Jakarta : FKUI. hal: 1923-24.

WHO.(2010).Childhood Overweight and Obesity. Web site : http://www.who.int/dietphysicala ctivity/childhood/en/Diakses pada 10desember 2018

WHO.(2017). Prevalensi Kejadian DiabetesMelitus.website :who.int/mediacentre/ factsheets/fs312/en/Diakses tanggal 25 Desember 2018. 